\title{
PRELIMINARY OBSERVATIONS ON THE POSSIBLE INFLUENCE OF TOXIC MINE WASTE ON BIRD POPULATIONS OF KISSISSING LAKE, MB
}

JON AND NAOMI GERRARD, 119 Brock St., Winnipeg, MB R3N OY5

\section{Introduction}

From 1928-1951, the Sherritt-Gordon mine operated at Sherridon in northern Manitoba, producing copper and zinc. Over the course of its life, the mine produced 166,093 tonnes of copper, 135,108 tonnes of $50 \%$ zinc concentrate and small amounts of silver and gold. ${ }^{1}$ During this period, a large mine tailings pile (Figure 1) accumulated near Sherridon on the shore of Camp Lake (Figure 2). From its inception, the mine tailings pile has progressively acidified and has leached metals into adjacent Camp Lake and from Camp Lake to Kississing Lake. The latter is a large lake centred at $55^{\circ} 10^{\prime} \mathrm{N}$ and $101^{\circ} 20^{\prime} \mathrm{W}$, within the boreal forest region of Manitoba and located east of Flin Flon. It has a surface water area of $275 \mathrm{~km}^{2}$ and an irregular shoreline with many islands. The water from Kississing Lake flows north into the Churchill River.

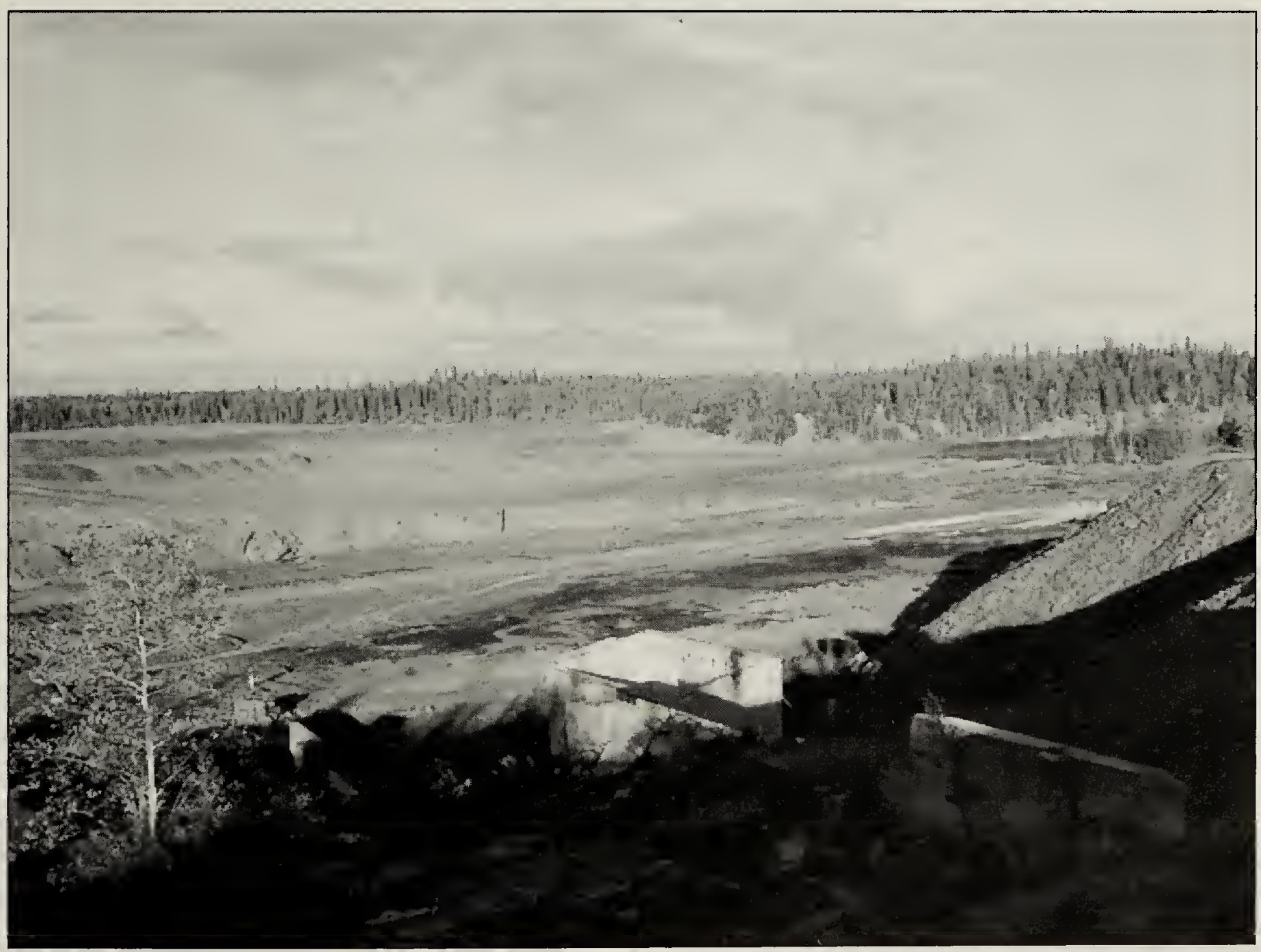

Figure 1. Sherritt-Gordon mine tailings pile, July 2005. The runoff from the pile collects on the right before it enters Camp Lake. Jon Gerrard 


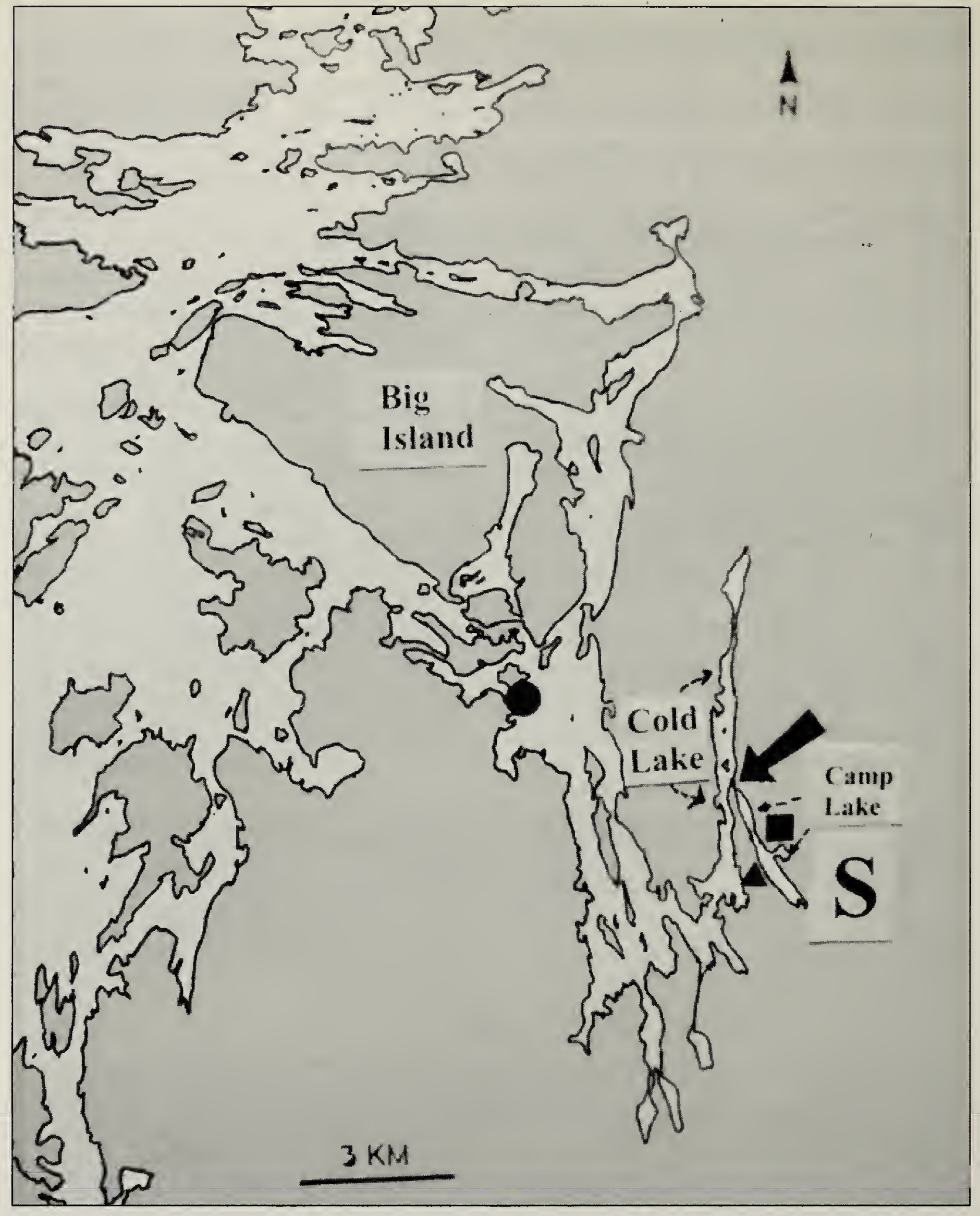

Figure 2. Southeast arm of Kississing Lake including the long bay named 'Cold Lake'. S = community of Sherridon; the arrow points to the site of the discharge from Camp Lake into Kississing Lake; $\mathbf{\square}=$ Serridon mine tailings pile; $\boldsymbol{\Delta}=$ Kenanow Lodge and the small community of Cold Lake; = Kississing Lake Lodge

Little has been done to reduce the leaching of toxic metals from the tailings pile and they have leaked extensively into adjacent Kississing Lake. Indeed, as Moncour reports (p. v), "the annual loading of acid, sulfate, and metals from Camp Lake to an adjacent lake [Kississing Lake] are extreme."

Studies of Kississing Lake completed in 2004 show that the impact of the toxic metals is now present at 
least $9 \mathrm{~km}$ from the site of the discharge of water from Camp Lake into Kississing Lake (Figure 3 ), and there is evidence of increased levels of zinc and copper extending $20 \mathrm{~km}$ from the site. $^{2}$ What is particularly disturbing is that "sediment grabs collected throughout Cold Lake, and further out into Kississing Lake toward [Kississing Lake] Lodge contained no or very few macroinvertebrates that were observable with the naked eye. Molluscs, including piisid and sphaerid clams, amphipods, chironomid larvae, large oligochaetes, and other commonly encountered benthic fauna were conspicuously absent in sediment samples from Cold Lake and the lower portion of Kississing Lake toward the junction with Cold Lake" ( $p$. $170) .^{2}$

The report continues (p. 170): "The lack of benthic invertebrates in Cold Lake and Kississing Lake as far away as [Kississing Lake] Lodge and beyond was also evident in nearshore [within 10 meters of the shoreline] areas. Reconnaissance observations of the littoral area along the shore of Sherlett Lake and other local reference lakes revealed an abundance of bivalves, including unionids, at least three gastropod species, crayfish, larval insects, leaches, juvenile and small fish. Molluscan taxa were not observed in nearshore areas of Cold Lake or Kississing Lake south of the Lodge."

It is noteworthy that concentrations of cadmium, copper, and zinc found in sediments in the part of Kississing Lake near the outlet from Camp Lake were all found to exceed the Probable Effects Level guidelines for freshwater life protection provided by the Canadian Council of Ministers of the Environment for acceptable contaminant concentrations in the environment. ${ }^{2}$ In addition, concentrations of arsenic, chromium and mercury in the sediments of this region of Kississing Lake exceeded the lower Interim Sediment Quality Guidelines for freshwater. ${ }^{2}$

In view of the extensive evidence of toxicity of zinc and copper in the sediments on macroinvertebrates, we looked to see if there were effects on bird species in the area, in particular on bird species that feed on fish and nearshore invertebrates.

\section{Methods}

A shoreline survey for waterbirds was conducted from July 25-27, 2005 using techniques developed and applied on Besnard Lake, Saskatchewan from 1976-2005.3.4 Besnard Lake is a boreal forest lake with many similarities to Kississing Lake. It is located at $55^{\circ} 20^{\prime} \mathrm{N}, 106^{\circ} 00^{\prime} \mathrm{W}$, has a water area of $177 \mathrm{~km}^{2}$ and, like Kississing Lake, has an irregular shoreline with many islands. Also similar to Kississing Lake, Besnard Lake is located at the southern boundary of the Churchill River Upland. ${ }^{6}$ Water from both lakes flows north into the Churchill River. Both are excellent fishing lakes, and both have two fishing lodges. ${ }^{7}$

The shoreline of Kississing Lake in the region closest to the discharge from Camp Lake into Kississing Lake was divided into $8-\mathrm{km}$ sections. Fourteen of 27 sections were surveyed (one of these only partially). Censuses were conducted with three observers in a motorized boat traveling 20-100 m from shore at a speed of $8-16 \mathrm{~km} / \mathrm{hr}$. Censuses were conducted during daylight hours when winds were less than $32 \mathrm{~km} / \mathrm{hr}$ and visibility was good. White Pelicans were only counted if the birds were perched on a rock, swimming in the water, or flying low over the water. Pelicans flying high over the lake were not counted, as they could 


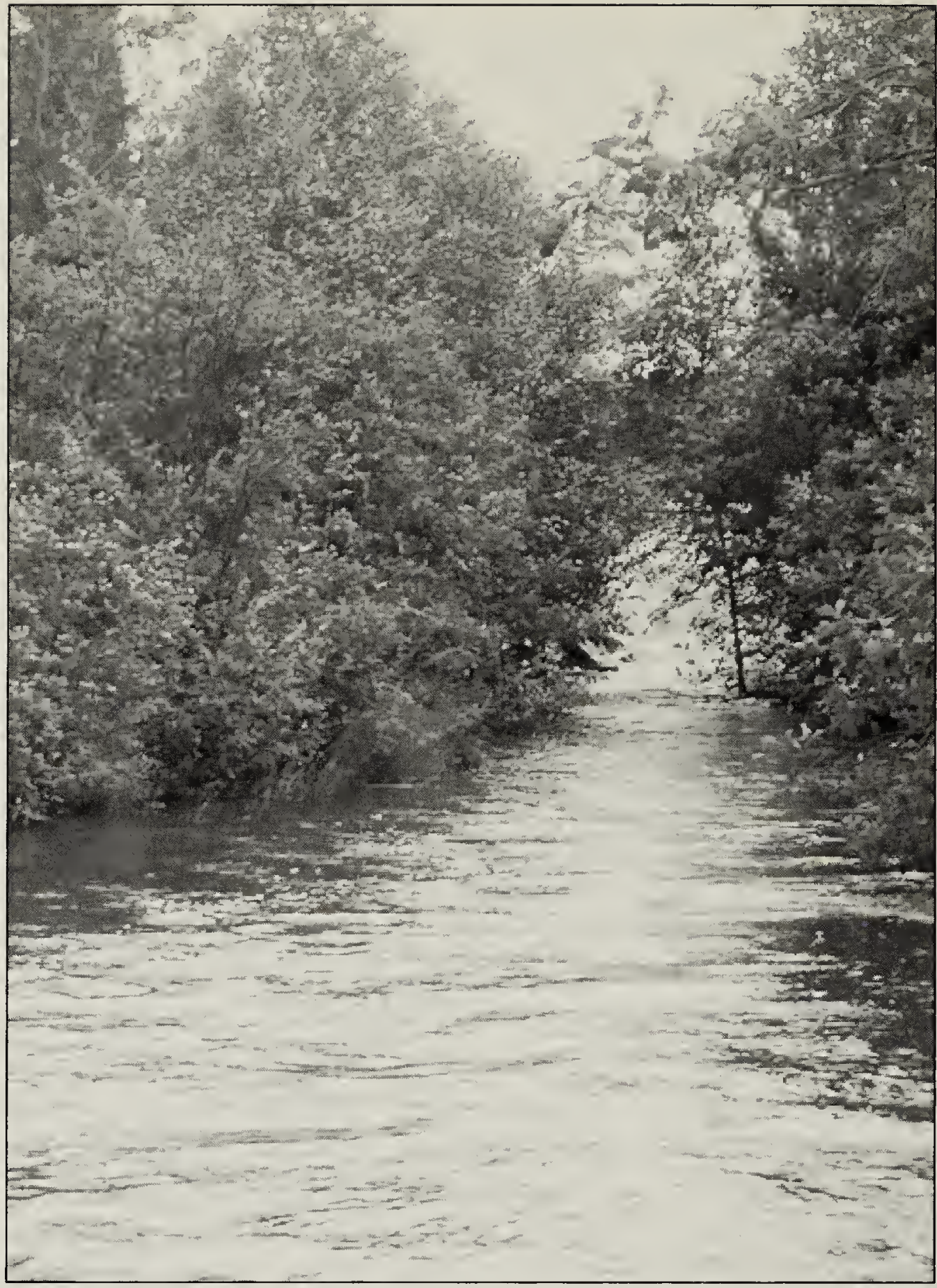

Figure 3. The stream that flows from Camp Lake into Kississing Lake, late July 2005.

have been traveling some distance rather than feeding in that section of the lake.

For each section, the distance by boat from the Camp Lake discharge into Kississing Lake to the mid-point of the section was measured and recorded. Trends for an increase in bird populations as the distance increased from the site of the discharge of Camp Lake into Kississing Lake were analyzed using a correlation coefficient.

\section{Results}

For eight species of waterassociated birds, there was an increase in the number of birds seen per section the farther the section was located from the outlet of Camp Lake into Kississing Lake (Table 1). This was particularly noticeable for six $s$ e c i e s. Mergansers (Redbreasted and $\mathrm{C} O \mathrm{~m} \quad \mathrm{~m} \quad \mathrm{n}$ mergansers combined) and Spotted Sandpipers were absent from the sections of Kississing Lake adjacent to the Camp Lake discharge, and increased in numbers farther from this site. The pattern was similar for pelicans. For pelicans, this trend was stastitically significant $(r=0.63$, $p<0.05)$. Bald Eagles, Common Loons and white-headed gulls (Herring and Ring-billed gulls combined) were present in sections near the Camp Lake discharge, but increased in numbers the farther the section was from the site. For adult and immature Bald Eagles combined, this increase was significant $(r=0.66, p<0.05)$. Similarly, for white-headed gulls the increase was significant $(r=0.54, p<0.05)$. No successful Bald Eagle nests were found closer than $12 \mathrm{~km}$ from the Camp Lake discharge site, however, an empty nest present at $7.5 \mathrm{~km}$ may well have been built in the last ten years. Doublecrested Cormorants and Common Terns were absent near the discharge 
Table 1: Number of birds seen per $8 \mathrm{~km}$ of shoreline on Kississing Lake $(\mathrm{KL})$, and comparison with Besnard Lake (BL)

\begin{tabular}{|c|c|c|c|c|c|}
\hline & $\mathrm{KL}$ & $\mathrm{KL}$ & KL & $\begin{array}{l}\text { All } \\
\text { KL* }\end{array}$ & $\begin{array}{l}\text { All } \\
\mathrm{Bl} \text { ** }\end{array}$ \\
\hline $\begin{array}{l}\text { Distance from Camp Lake } \\
\text { discharge }\end{array}$ & $<5 \mathrm{~km}$ & $\begin{array}{l}\geq 5 \mathrm{~km} \\
\leq 11 \mathrm{~km}\end{array}$ & $>11 \mathrm{~km}$ & & \\
\hline No of sections & 3 & 6 & 5 & 14 & 25 \\
\hline Bald Eagles - adults & 1 & 0.8 & 2.8 & 1.5 & 1.4 \\
\hline - immatures & 0 & 0.2 & 1.5 & 0.54 & 0.24 \\
\hline - adults and immatures & 1 & 1 & 4.3 & 2.0 & 1.64 \\
\hline - empty nests & 0 & 0.2 & 0.4 & 0.2 & 0.4 \\
\hline - nests with young & 0 & 0 & 0.4 & 0.14 & 0.3 \\
\hline Common Loons - adults & 2.7 & 7.5 & 6.8 & 5.9 & 2.2 \\
\hline - young & 0.7 & 1 & 0.5 & 0.77 & 0.64 \\
\hline Pelicans & 0 & 0 & 3.2 & 1.0 & 2.1 \\
\hline Mergansers & 0 & 1 & 3.4 & 1.77 & 4 \\
\hline Common Goldeneye & 0 & 0 & 0 & 0.0 & 3.4 \\
\hline Belted Kingfisher & 1.3 & 1 & 1 & 1.08 & 0.6 \\
\hline White-headed Gulls & 5 & 6.3 & 22 & 10.8 & 6.9 \\
\hline Mallards & 2.7 & 0.2 & 0.3 & 0.8 & 0.4 \\
\hline Spotted Sandpipers & 0 & 0.7 & 2 & 0.8 & 0.8 \\
\hline Double-crested Cormorants & 0 & 0 & 2.5 & 0.8 & 0.3 \\
\hline Common Terns & 0 & 0 & 1.3 & 0.4 & 0.2 \\
\hline
\end{tabular}

site, but present farther away. Belted Kingfishers and Mallards were both present in the section closest to the discharge site. Belted Kingfishers were found in a similar density farther away, while Mallards were at a lower density.

Table 1 compares sections on Kississing Lake which were close to the discharge from Camp Lake, to those $5-10 \mathrm{~km}$ away, to those more than $11 \mathrm{~km}$ away, and to 8-kilometre sections surveyed with a similar method on Besnard on July 4-11, 2005. In comparison to Besnard Lake, the number of mergansers, pelicans and Spotted Sandpipers is lower near the Camp Lake discharge into Kississing Lake as is the number of Bald Eagle nests with young. In contrast, the number of loons near the Camp Lake discharge was not lower than Besnard Lake sections, even though it was lower than Kississing Lake sections further from the discharge site. No Common Goldeneye were seen on Kississing Lake, while these ducks were present at an average of 3.4 per $8-\mathrm{km}$ section on Besnard Lake.

\section{Discussion}

We suspect that the decrease in the number of Bald Eagles, White Pelicans and gulls close to the discharge site from Camp Lake to Kississing Lake and the absence of mergansers, Double-crested Cormorants and Common Terns near the discharge site is related to absence of prey species close to the site and/or the toxicity of prey species close to the site.

For mergansers, the reason for their absence near the discharge site may be that mergansers feed primarily close to the shoreline on small fish and invertebrates, which are severely affected by the toxic mine wastes. In 
contrast to mergansers, loons were present near the discharge site. Loons primarily feed in deeper water, and there may be enough movement of fish from other parts of Kississing Lake, and/or through streams from adjacent lakes, into such deeper waters areas.

Bald Eagles feed on larger fish. The relative decrease in the number of Bald Eagles near the discharge site may be a reflection either of decreased numbers of large fish in this area, or possibly a result of an accumulation of toxic metals. We also found an absence of Bald Eagle nests with young in the region of Kississing Lake adjacent to the Camp Lake discharge. This observation is of concern as it suggests the possibility of a build up of toxic metals in the bodies of the eagles which then interferes with reproduction, as has been found for mercury. ${ }^{5}$

\section{The absence of Common Goldeneye} on Kississing Lake is of concern, in that these birds eat invertebrates in the nearshore regions of the lake. It is possible that they are affected at a larger distance from the Camp Lake discharge than the other species, since we were told by Tim Matheson that goldeneye are seen regularly on other parts of Kississing Lake.

While the observations reported here suggest that there have been adverse effects of the toxic mine wastes on bird populations, as might be predicted from the studies of fish and invertebrates, the results will need to be confirmed and extended in future years.

\section{Acknowledgements}

We thank Tim and Val Matheson, our hosts while we were on Kississing Lake. We are also grateful for the hospitality we received from Mayor Nick Benyk and his council while we were in Sherridon.

1. MONCOUR, M. C. 2004. Release, Transport and Attenuation of Metals from an Old Tailings Impoundment, Sherridon, Manitoba. M.Sc. Thesis, University of Waterloo.

2. UMA ENGINEERING LTD. and SENES CONSULTING LTD. 2004. Site-specific assessment of human health and ecological risks from the abandoned mine site, Sherridon/Cold Lake, Manitoba. Report to Manitoba Conservation.

3. GERRARD J. M., BORTOLOTTI G. R., DZUS E. G., GERRARD P. N., WHITFIELD D. W .A. 1990. Boat census of Bald Eagles during the breeding season. Wilson Bulletin 102:720-726

4. GERRARD J. M., DZUS E. H., BORTOLOTTI G. R., GERRARD P. N. 1993. Water-bird population changes in 1976-1990 on Besnard Lake, Saskatchewan: increases in loons, gulls, pelicans. Canadian Journal of Zoology 71:1681-1686

5. NEWTON, I. 1979. Population Ecology of Raptors. Buteo Books, Vermillion, South Dakota.

6. FUNG, K., BARRY, B. and WILSON M., Eds. 1999. Atlas of Saskatchewan. University of Saskatchewan, Saskatoon SK.

7. LYSACK W. 2005. Kississing Lake Creel Survey 2004. Manuscript Report No. 2005-02 to Manitoba Water Stewardship.

"... a blue-throated hummingbird, in active flight around its Southwestern habitat, has a pulse rate of nearly 1,200 beats per minute. A turkey's heart barely exceeds $90 . "$

Scott Weidensaul, The Birder's Miscellany, p.14 